\title{
Standing to Sue in Public Actions: Is it a
}

\section{Constitutional Requirement?}

\section{Raoul Bergert}

Confusion twice-confounded reigns in the area of federal jurisdiction described as "standing to sue." That concept, it has been justly observed, is "among the most amorphous in the entire domain of public law," one of "uncertain content," 1 of such complexity that Justice Frankfurter, a pioneering student of federal jurisdiction, "found himself reduced to a nearly unprecedented degree of inarticulateness" in dealing with one of its many aspects. ${ }^{2}$ Not a little of the confusion originated in Frothingham v. Mellon, ${ }^{3}$ which left uncertain whether "standing" was a constitutional requirement or simply a "rule of selfrestraint." A contributing factor was Justice Frankfurter's own attempt to ground the standing doctrine firmly on constitutional compulsions. In endowing the Court with "judicial Power," he stated, Article III "presupposed an historic content for that phrase," and in limiting the sphere of judicial action to "Cases" and "Controversies" the Framers had reference to "the familiar operations of the English judicial system," whereunder "[j]udicial power could come into play only in matters that were the traditional concern of the courts in Westminister and only if they arose in ways that to the expert feel of lawyers constituted 'Cases' or 'Controversies." "G Given a document which employed familiar English terms-e.g., "admiralty," bankruptcy," "trial by jury" - it is hardly to be doubted that the Framers contemplated resort to English practice for elucidation, and so the Supreme Court has often held. ${ }^{6}$ Indeed, on the very issue of "judicial Power"

+ A.B. 1932, University of Cincinnati; J.D. 1935, Northwestern University; LL.M. 1938, Harvard University.

1. Hearings on S. 2097 Before the Subcomm. on Constitutional Rights of the Senale Comm. on the Judiciary, 89th Cong., 2d Sess. 498 (March 1966) [hereinafter cited as Hearings]. "Uncertainty," said John Streater, invoking a maxim in his defense against a commitment by Parliament in 1654, is "the mother of all debate and confusion, than which there is nothing more odious in law." Streater's Case, 5 How. St. Trials 365, 399.

2. L. JafFe, Judicial Control of Administrative Action 461 (1965).

3. 262 U.S. 447 (1923).

4. Flast v. Cohen, 392 U.S. 83, 92 (1968).

5. Coleman v. Miller, 307 U.S. 433,460 (1939) (dissent). This was a "political question" case; Justice Frankfurter went on to lift his view to the level of generalized doctrine in Joint Anti-Fascist Refugee Comm. v. McGrath, 341 U.S. 128, 150.59 (1951) (concurring opinion).

6. The language of the Constitution cannot be interpreted safely except by refercnce to the common law and to British institutions as they were when the instrument was framed and adopted. The statesmen and lawyers of the Convention who submitted 
Madison emphasized in the Convention that it ought "to be limited to cases of a Judiciary Nature," implying that past practice would supply the criterion. ${ }^{7}$

It has been too easily assumed, however, that English practice had at its core the necessity of showing injury to a personal interest as a prerequisite to an attack on jurisdictional usurpation. ${ }^{8}$ In seeking to clarify Frothingham in Flast v. Cohen, moreover, the Court, in my opinion, has further confused analysis by extracting from the separation of powers and advisory opinion doctrines "implicit policies embedded in Article III"9 with which to bolster dubious implications drawn from the "case or controversy" phrase. ${ }^{10} \mathrm{~A}$ first step towards clarification would be to clear the ground of unhistorical notions of constitutional restrictions, to free consideration of the perplexing and wide-ranging issues of policy that cluster about the problem of standing from the constriction of fancied constitutional bonds. I propose to show that the English practice on which Justice Frankfurter relied did not in fact demand injury to a personal interest as a prerequisite

it to the ratification of the Conventions of the thirteen States, were born and brought up in the atmosphere of the common law and thought and spoke in its rocabulary. They were familiar with other forms of government, recent and ancient, and indicated in their discussions earnest study and consideration of many of them, but when they came to put their conclusions into the form of fundamental law in a compact draft, they expressed them in terms of the common law, confident that they could be shortly and easily understood.

Ex Parte Grossman, 267 U.S. 87, 108-09 (1925). As was said in Glidden Co. v. Zdanol, 370

U.S. 530, 563 (1962),

one touchstone of justiciability to which this Court has frequently had reference is whether the action sought to be maintained is of a sort "recognized at the time of the Constitution to be traditionally within the power of courts in the English and American judicial systems."

See also Goebel, Constitutional History and Constitutional Law, 38 Colua. L. REv. 555, 557 (1938).

7. 2 M. Farrand, Records of the Federat Convention of 1787, at 411 (1911) (hiereinafter cited as FARRAND].

8. Joint Anti-Fascist Refugee Comm. v. McGrath, 341 U.S. 123, 151-54 (1951) (Frank:furter, J., concurring). Professor Bickel deduces from the fact that the judicial power "may be exercised only in a case," that crurts "may not decide non-cases, which are not adversary situations and in which nothing of immediate consequence to the parties turns on the results." Bickel, Foreword: The Passive Virtues, The Supreme Court, 1960 Term, 75 HARv. L. REv. 40, 42 (1961) [hereinafter cited as Bickel].

9. 392 U.S. 83,96 (1968).

10. That the matter is by no means academic may be deduced from the fact that Chairman Sam Ervin of the Senate Subcommittee on Constitutional Rights felt constrained in 1966 to call hearings in order to ascertain from divers scholars whether Congress was empowered to confer standing, not dependent upon a personal interest. to attack the constitutionality of legislation that would assist the educational and welfare programs of religious institutions. Hearings 5. In those hearings government counsel repeatedly urged that such legislation would raise constitutional doubts. Id. 76, 85, 127, 137. Professor P. G. Kauper stated that "absent a showing of injury" to the suitor in some "specific or concrete way," he "would not suppose that Congress has the power to direct the Federal courts to take jurisdiction of such citizen's suits." Id. 502. Professor A. S. Miller stated that there is "some doubt of the extent to which Congress can confer 'standing' upon those the Supreme Court has said do not have it." Id. 509. 
to attacks on jurisdictional excesses, ${ }^{11}$ and that neither the separation of powers nor advisory opinion doctrines as originally envisaged require insistence on a personal stake as the basic element of standing to make such challenges.

Unlike "case or controversy," which can summon the express terms of Article III, "standing" is not mentioned in the Constitution or the records of the several conventions. It is a judicial construct pure and simple ${ }^{12}$ which, in its present sophisticated form, is of relatively recent origin. Professor Jaffe encountered "no case before 1807 in which the standing of the plaintiff is mooted ..., ,'13 and found that objections to the standing of a private individual to enforce a "public right" were first squarely presented in $1897 . .^{14}$ Locus standi was employed by two English Courts in 1874 and 1879 in not really relevant circumstances, ${ }^{15}$ and appears in connection with referral by the House of Commons to a Court of Reference of objections that certain private bills may interfere with private rights of others. ${ }^{16}$ As late as 1955, an English writer examining the availability of the writ of certiorari could say that the subject of locus standi had not been "treated in a satisfactory way by any one, judge or jurist."17 In any case "standing" was neither a term of art nor a familiar doctrine at the time the Constitution was adopted. Although it has been explained as a description of "the constitutional limitation on the jurisdiction of the Court to 'cases' and 'contro-

11. This is not a novel proposition. In a pathbreaking article, Professor Jafte sought to demonstrate via the history of mandamus that "the public action-an action brought by a private person primarily to vindicate the public interest in the enforcement of public obligations-has long been a feature of our English and American law." Jaffc, Standing to Secure Judicial Review: Private Actions, 75 HARv. L. REv. 255, 902 (I961) [hereinafter cited as Jaffe, Private Actions], summarizing his companion article, Standing to Secure Judicial Review: Public Actions, 74 HARv. L. REv. 1265 (1961) [hercinafter cited as Jaffe, Public Actions]. In the latter he noted that Frothingham appealed to "a ques. tionable dogma." Id. 1266. In Hearings 451 , he characterized the requirement that a plaintiff have "a special, pecuniary interest" as "unhistorical."

12. Jaffe, Private Actions 256.

13. Jaffe, Public Actions 1270. There is an earlier American case, State v. Corporation of New Brunswick, 1 N.J.L. 393 (1795), in which the argument was made, without cmploying the word "standing," and was rejected. For discussion sec TAN 99 infra. See note 98 infra for a rejection in a quo warranto case in 1789.

14. Jaffe, Public Actions 1271-72.

15. James v. The Queen, [1874] $5 \mathrm{Ch}$. D. 153,160 (one to whom a statute does nut make a grant has no locus standi to compel one to him); In re Gold Co., [1879] 12 Ch. D. 77, 83 .

16. Constable, Principles and Practice Affecting Loctus Standi, 9 JuRtD. REv. 47, 55 (1897): "The principle of loctus standi is that there is something in the bill which, if passed into law, would injure the parties petitioning" (quoting Mr. Richards). "The fact that the words locus standi have not found their way into the indices of the English digests itself suggests relative novelty. And to this day in England "there is no serious trouble over standing (i.e., locts standi)." Wade, Anglo-American Administrative Law: More Reflections, 82 L.Q. REv. 226, 249 (1966).

17. Yardley, Certiorari and the Problem of Locus Standi, 71 L.Q. REv. 388, 398 (1955). 
versies," "18 it apparently entered our law via Frothingham in 1923.10

When we turn to pre-Constitution English law for light on the meaning of "case or controversy," we find that attacks by strangers on action in excess of jurisdiction were a traditional concern of the courts in Westminster. The writ of prohibition supplies perhaps the clearest example. Coke tells us of a complaint by the clergy to the King of undue granting of writs of prohibition by the courts against the exercise of ecclesiastical jurisdiction, which the judges were then called upon to answer. "[A]11 the judges of England, and the barons of the Exchequer, with one unaminous consent," records Coke, made answer in a document known as the Articulo Cleri. In their Third Answer the judges stated:

Prohibitions by law are to be granted at any time to restraine a court to intermeddle with, or execute any thing, which by law they ought not to hold plea of, and they are much mistaken that maintaine the contrary .... And the kings courts that may award prohibitions, being informed either by the parties themselves, or by any stranger, that any court temporall or ecclesiasticall doth hold plea of that (whereof they have not jurisdiction) may lawfully prohibit the same, as well after judgement and execution, as before. ${ }^{20}$

No English court, so far as I can discover, has ever rejected the authority of Articulo Cleri or denied that a writ of prohibition may be granted at the suit of a stranger. On the contrary, Coke was cited by the 18th century Abridgments ${ }^{21}$ and by English courts throughout the 19th century, ${ }^{22}$ and his rule remains the law in England today. ${ }^{23}$ Thus at the time of the Revolution, the "courts in Westminster" afforded to a

18. Barrows v. Jackson, 346 U.S. 249, 255 (1953); C. Wrught, FederAl CourTs 36 (1963). states that "standing to sue is an element of the federal constitutional concept of case or controversy." "See also note 8 supra.

19. Professor Jaffe states that "[t]he first significant controversy . . . concerning standing had reached the Supreme Court in 1911," but that the Court "found it unnecessary to decide the standing question." The "criterion of standing was brought into focus" with Baltimore \& Ohio R.R. v. United States, 264 U.S. 258 (1924). Jaffe, Private Actions 261-262.

20. 2 E. COKE, INSTITUTES OF THE LAWS OF ENGLAND 602 (1797) [hereinafter cited as Inst.]. "In Roman law it was open to any citizen to bring an actio popularis in respect of a public delict or to sue for a prohibitory or restitutory interdict for the protection of res sacrae and res publicae." S. DE SMITH, JudICIAL REVIEW OF ADMiNistative Action 423 (2d ed. 1968) [hereinafter cited as DE SMrrm].

21. 4 J. Comyns, Digest, "Prohibition" (E) (I766); 4 Mr. BACoN, ARrugsest, "Prohibition" (G) (3d ed. 1768).

22. In TVadsworth v. Queen of Spain [1851] 17 Q.B. 171 214, Lord Campbell stated: "we find it laid down in books of the highest authority that, where the court to which prohibition is to go has no jurisdiction, a prohibition may be granted upon the request of a stranger, as well as of the defendant himself. 2 CokE 607; Com. Dig. Prohibition (E)." See also MIajor of London v. Cox [1867] L.R. 2 E. \& I. App. 239, 279 (H.L.); Worthington v. Jeffries [1875] L.R. 10 C.P. 379, 383. See note 108 infra.

23. H. WADE, Adamnistratme Law 125-26 (2d ed. 1967) [hercinafter cited as Wade]. 
stranger a means of attack on juridictional excesses without requiring a showing of injury to his personal interest.

Coke was a revered figure in the Colonies, and his record of Articulo Cleri was presumably familiar to Colonial lawyers. ${ }^{24}$ In addition, his doctrine had been picked up by the Bacon and Viner Abridgments, to which they frequently turned, as well as by the respected Comyns' Digest. ${ }^{25}$ Of course the availability of prohibition did not constitute "common law precedent on standing to attack the constitutionality of a statute,"26 both because written constitutions were a distinctive product of post-revolutionary America, and because the doctrine of "constitutionality" was a peculiarly American development. But a challenge to action in excess of authority conferred by the Constitution was well within the rationale of the writ of prohibition.

There was also the analogous practice of certiorari. Both the writs of certiorari and prohibition, said Lord Atkin,

are of great antiquity, forming part of the process by which the King's Courts restrained courts of inferior jurisdiction from exceeding their power. Prohibition restrains the tribunal from proceeding further in excess of jurisdiction; certiorari requires the record or order of the court to be sent up to the King's Bench Division, to have its legality inquired into, and, if necessary, to have the order quashed. It is to be noted that both writs deal with questions of excessive juridiction. ${ }^{27}$

Certiorari, stated Chief Justice Holt in 1702, would issue to examine the "proceedings of all jurisdictions erected by Act of Parliament ... . to the end that this court may see that they keep themselves within their jurisdiction; and if they exceed it, to restrain them."28 That certiorari was available to a stranger may be inferred from a 1724 case

24. In New York, "Coke was by all odds the writer most used and cited. There are many indications that this was true in other provinces." Goebel, supra note 6, at 564 n.25. Jefferson stated that there never was "one of profounder learning in the orthodox doctrines of the British Constitution or what is called British rights" than Coke. E. Conw1N, THE DOCTRINE OF JUDICIAL REVIEW 31 n.45 (1914).

25. See note 21 supra; C. Viner, Abridgment, "Prohibition" (M) 14 (1743). "A lot of American law came out of Bacon's and Viner's Abridgments." Gocbel, Ex Parte Clio, 54 Colum. L. REv. 450, 455 (1954). Justice Willes stated in Mayor of London v. Cox [1867] L.R. 2 E. \& I. App. 239, 285 (H.L.): "the law is laid down in Comyn's Digest." 2 J. ADAxrs, LEGAL PAPERS (Wroth \& Zobel eds. 1965) contains frequent citations of the Abriclginents by James Otis, Adams, and Blowers. Id. 128 n.73, 163, 228, 269, 284, 341, 350, 424, 428, 490.

26. Jaffe, Public Actions 1308.

27. Rex v. Electricity Commissioners [1924] 1 K.B. 171, 204.05. Lord Atkin statcd that he could "see no difference in principle between certiorari and prohibition, except that the latter may be invoked at an earlier stage." Id. at 206.

28. Rex v. Inhabitants in Glamorganshire, 91 Eng. Rep. 1287, 1288 (1702) (certiorari to bring up a levy of moneys to repair Caerdiffe Bridge). If there was a "personal stake" quaere whether it amounted to a "cause of action." See note 47 infra. 
which drew a distinction between a party aggrieved and "one who comes merely as a stranger," for purposes of deciding whether issuance of the writ was discretionary or a matter of right. ${ }^{20}$ In 1870 an English court examining the writ looked to "the very analogous case of prohibition,"30 and without an air of fresh-minting law the Court of Appeal flatly stated in 1957 that "the remedy by certiorari ... extends to any stranger." 31 I know of no English case that has denied this proposition.

Originally, both certiorari and prohibition "dealt almost exclusively with the jurisdiction of what is described in ordinary parlance as a Court of Justice"; 32 but very early they were employed with respect to what we term "administrative" functions. Because the justices of the peace were the local county administrators, charged with supervising road construction and maintenance, licensing alehouses, setting wage-scales for laborers and apprentices and administering the poorlaws, and were at the same time courts of record, ${ }^{33}$ review of administrative functions was handily accomplished by means of these self-same writs. As Professor de Smith remarks:

It was assumed that the writs of certiorari and prohibition by which [the justices] were controlled in their capacity as courts of summary jurisdiction, were equally appropriate devices for superintending the exercise of their multifarious governmental functions. All those functions of the justices which were not purely ministerial were regarded for this purpose as being judicial: no separate category of discretionary "administrative" acts, immune from the reach of certiorari and prohibition, was yet recognised. A no less broad conception of "judicial" functions governed review of orders made by the Commissioners of Sewers, who presided over a court of record which performed administrative duties under judicial forms. ${ }^{34}$

29. Arthur v. Commissioners of Sewers, 88 Eng. Rep. 237 (I725). The case was so read by Justice Blackburn in Regina v. Justices of Surrey, [1870] L.R. 5 Q.B. 466, 472-73.

30. Id. at 472 .

31. Regina v. Thames Magistrates Court, ex parte Greenbaum [1957] Local Gov't Rep. 129, 132, 135-36. In England

an applicant for certiorari or prohibition does not have to show that some legal right of his is at stake. If the action is an excess or abuse of power, the court will quash it at the instance of a mere stranger ... [T] hese remedies are not restrieted by the notion of locus standi. Every citizen has standing to invite the court to prevent some abuse of power, and in doing so he may claim to be regarded not as a meddlesome busybody but as a public benefactor.

WADE 125-26.

32. Rex v. Electricity Commissioners [1924] 1 K.B. 171, 205.

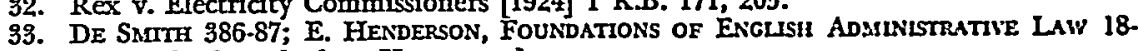
25 (1963) [hereinafter cited as HENDERSON].

34. DE SMITH 387. Review of a non-judicial function of the Commissioners is illustrated by Arthur v. Commissioners of Sewers, 88 Eng. Rep. 237 (1725), in which certiorari brought up an order ousting plaintiff who had been chosen by the Commissioners as 
In the course of the meandering development of English administrative law many such functions were transferred from "caurts of record" to administrative agencies. In keeping with existing practice Parlinment not infrequently provided for review by certiorari-as, for example, in the case of Poor Law administration. And despite the lack of such express provisions in other statutes, from which the courts might have inferred that Parliament intended to exclude certiorari in certain cases, it was concluded instead that "common-law certiorari and prohibition could properly issue to other authorities discharging similar functions." "3a In one such case the court rejected an attempt by the Inclosure Commissioners to question whether prohibition would lie to review an attempted enclosure with the remark that the case was "too clear." ${ }^{36}$ Evaluation of a colonial lawyer's hypothetical appraisal of English practice in curbing action in excess of juriscliction should not therefore be made to turn an a "court of record" distinction which the English judiciary, so respectful of precedent, faund of no moment. Colonial observers would see administrative functions being reviewed

their clerk at an earlier meeting. If, as Professor Henderson emphasizes, the Commissioners, fike the justices of the peace, were courts of record, HeNDrRson 112, 116, the predominant consideration was preyention of jurisdictipnal excesses, as tyo notable utterances testify. In Commins v. Massam, March 196 (1643), Justice Heath stated:

notwithștanding that the act leaves the proceedings to the discretion of the Comnmissioners [of Sewers], nevertheless this discretion is examinable and controllable in this Court. Suppose that the Commissioners do anything without or against their commission, without doubt this is reformable and examinable here.

Quoted in Henderson 146. In the Caerdiffe Bridge Case (Rex v. Inhabitants in Glamorgan. shire, 91 Eng. Rep. $1287^{\circ}$ (1702)), the justices of the peace had levicd moncy far repair of the bridge, and objection to certiorari was made that a new statute had reppsed the jurisdiction, i.e., the discretion, in the justices. To this Chief Justice Holt replied:

this Court will examine the proceedings of all jurisdictions erected by Act of Parliament. And if they, under pretense of such Act, proceed to incroach juriscliction to themselves greater than the Act warrants, this Court will send a certiorari to them .. to the end that this Court may see, that they keep themselves within their jurisdiction, and if they exceed it, to restrain them.

Id. at 1288 .

35. DE SMrTh 388.

36. Church v. Inclosure Commissioners, 142 Eng. Rep. 956 (1862). Rex y. Electricity Commissioners, [1924] 1 IK.B. 171, 209, noted this act of a distinguished bench.

The relevance of the early cases was made explicit in 1924 when Rex $v$. Electricily Commissioners pointed to the Caerdiffe holding that "certiorari lies to justices of peace in a county in respect of a statutory duty to fix a rate for the repair of a county bridge." Id. 205. Stress in that case upon the "judicial" nature of the revicwable administrative function is to be read against the facts: "the Electricity Commissioners have ta decide whether they will constitute a joint authority in a district in accordance with law, and with what powers they will invest that body." In "deciding upon the scheme and in holding the inquiry, they are acting judicially . . . II Id. 206-07. Professor Handarson reminds us that the orders issued by the early courts of record are "very different from the judicial business 'between party and party' which is characteristic of courts of record." HENDERSON 116.

It would have been anomalous indeed had agency excesses been given immunity denied to judicial usurpations, and this at a time when deference to vaunted agency expertise lay far in the future. In applying the Caerdiffe ruling to purely administrative agencies the English courts were true to the common law canon that the scope of a principle is not limited to the facts that fortuitously gave it birth. 
without reason to conclude that future transfers from courts of record to administrative agencies would liberate those functions from surveillance.

In addition to prohibition and certiorari there were other writs, which had no "court of record" antecedents. An information in the nature of quo warranto antedates the statute of 9 Anne, which allowed anyone who so desired to make use of the name of the Glerk of the Crown, with the leave of Court, for the purpose of prosecuting usurpers of franchises. ${ }^{37}$ The breadth of the statute envisaged suits by a stranger; and at least one case in $1789^{38}$ held that the writ was available to a stranger, as had earlier been held with respect to other prerogative writs. The analogy to prohibition was clearly drawn in 1915, when Lord Reading observed that "a stranger to a suit can obtain prohibition ... and I see no reason why he should not in a proper case obtain an information of quo warranto." ${ }^{33}$

Professor Jaffe considers mandamus and injunctions as the "most significant prototypes the public action," certiorari of "considerably lesser significance," and prohibition and quo warranto least important of all.40 As a résumé of the American development this is unexceptionable, but it probably was not intended to describe the course of events in England, where the availability of prohibition and quo warranto as public actions, as Professor Jaffe himself notes, "has been clearer than that of either mandamus or injunction"11 and where even today certiorari and prohibition remain available to strangers.:2 Since

37. 9 Anne, c. 20 (1710). See Rex v. Trelawney, 97 Eng. Rep. 1010 (1705); J. SuOfit. Informations (Cruminal aNd Quo Warkanto) MANdamus and Prombition I12-14 (1883) [hereinafter cited as SHORTT].

38. Rex v. Smith, 100 Eng. Rep. 740 (1790), contains a note on Rex v. Brou'n (1789), which was an information in the nature of quo warranto that councilmen vere under disqualification because they had not received the sacrament within twelve months previous to the election as required by" statute. Erskine argued that "it does not appear here that the party making the application has any connection with the corporation." Lord Kenjon, however, held: "We are bound to grant this information. The law has said that the magistracy of the country shall be in the hands of those who profess the religion of the Church of England." Justice Ashurst added: "the ground on which this application is made is to enforce a general Act of Parliament, which interests all the corporations in the kingdom; and therefore it is no objection that the party applying is not a member of the corporation."

Cf. Rex v. Mrayor of Hartford, 91 Eng. Rep. 325 (1700), where quo warranto issued against the mayor and aldermen of Hartford to show "by what authority they admitted persons to be freemen of the corporation who did not inhabit in the borough. The motion was pretended to be on behalf of the freemen, who by this means were cncroaclied upon." See note 47 infra.

39. Rex v. Speyer [1916] L.R. 1 K.B. 595, 613. "Every subject," said Justice Lush, "has an interest in securing that public duties shall te exercised only by those competent to exercise them ...."Id. at 628 .

40. Jäfe, Public Actions 1269.

41. Id.

42. See note 31 supra. 
my concern is with the state of English law before 1787, with the question whether that law, as viewed by the Framers, could be understood to permit attacks by strangers upon jurisdictional usurpations, the early English practice in prohibition, certiorari, and quo warranto, which permitted such attacks, is for me the more significant.

For purposes of such attacks, I suggest, the early English mandamus practice was not highly relevant. Mandamus was largely designed to compel action by one who was under a duty to act, who was authorized to act in the premises; it was not a vehicle for the restraint of unauthorized action. As Blackstone put the distinction, mandamus was used to direct persons, corporations or inferior courts "to do some particular thing ... which appertains to their office and duty," while "encroachment of jurisdiction, or calling one coram non judice, to answer in a court which has no legal cognizance of the cause, is . . a grievance for which the common law has provided a remedy by the writ of prohibition."43

Mandamus, however, did have an important complementary role to play in the enforcement of duties colored with a public interest, duties in which the "personal interest" did not rise to the dignity of a "cause of action." In 1652 mandamus was granted to the parishioners and officers of the parish of Clerkenwell "to make scavengers that are elected to that office to serve the office." 44 In the Case of the Borough of Bossiny mandamus issued to hold an election for mayor; ${ }^{45}$ a mandamus commanded in 1733 that an election be held to fill a vacancy on the corporation of Esham; ${ }^{46}$ and it had issued in 1698 to compel justices of the peace "to make rates for the relief of the poor." 47 From such cases a colonial lawyer might well have concluded that mandamus was capable of issuance at the suit of a stranger who sought to assert the

43. 3 W. Blackstone, Commentaries" 110-11. 3 M. Bacon, Abridgment, "Mandamus" (A) (3d ed. 1768) states that the writ was used "to oblige inferior Courts and Maglstrates to do that Justice, which, without such Writ, they are in Duty, and by virtuc of their Offices, obliged to do." Compare J. Comyns, Digesr, "Mandamus" (B) (1766): it "docs not lie to prevent a Molestation against Law: As not to molest a Preacher." Regina v. P'cach, 91 Eng. Rep. 482 (1705). In denying a writ in such circumstances, Peat's Case, 87 Eng. Rep. 979 (1704), explained that "a mandamus is always to do something in exccution of law."

44. Anonymous, 82 Eng. Rep. 765 (1652).

45. 93 Eng. Rep. 996 (1735).

46. Anonymous, 94 Eng. Rep. 471 (1733).

47. Lidleston v. Mayor of Exeter, 90 Eng. Rep. 567 (1697)

Such cases, as well as Rex $v$. Mayor of Hartford, discussed supra note 38 , and Rex $v$. Inhabitants of Glamorganshire, supra note 28, speak against the narrow requircment of Tennessee Electric Power Co. v. TVA, 306 U.S. 118, 140 (1939), that a plaintiff who would complain of invalid action must show injury to "a legal right-one of property, one arising out of contract, one protected against tortious invasion, or one founded on a statute which confers a privilege." 
public interest, ${ }^{48}$ especially because the analogy of mandamus to prohibition was early drawn, and because Coke, who had unequivocally stated the availability of prohibition to strangers, also made a massive assertion of mandamus jurisdiction. ${ }^{40}$ To King's Bench, he declared in James Baggs' Case,

belongs authority, not only to correct error in judicial proceedings, but other errors and misdemeanors extrajudicial, tending to breach of peace, or oppression of the subjects, or to the raising of faction, controversy, debate or any manner of misgovernment, so that no wrong or injury, either private or public, can be done but what it shall be here reformed or punished by due course of law. ${ }^{50}$

This was not long after Articulo Cleri had categorically asserted the right of strangers to attack jurisdictional usurpations in prohibition proceedings. Scarcely less encompassing was Lord Mansfield's statement in 1762 that mandamus

was introduced to prevent disorder from a failure of justice and defect of police. Therefore, it ought to be used upon all occasions where the law has established no specific remedy, and where in justice and good government there ought to be one.51

The fact that mandamus subsequently "developed along more modest lines" 52 should not obscure the potential effect of these grandiose claims on the minds of the Founders. In weighing whether "case or controversy" was framed restrictively, we should not too hastily assume that the contemporary view was ours, but rather should consider that Coke's and Mansfield's sweeping assertions of mandamus jurisdiction reflected English practice in other prerogative writs. ${ }^{63}$

The early English practice in prohibition, certiorari, and quo warranto is not the sole indication of easy access to "public actions"; there were in addition the centuries-old "informers" actions. These went beyond making available procedures to control unlawful conduct, and

48. Professor Jaffe points out that "the lists of the cases in the digests strongly suggest that the plaintiff in some of them was without a personal interest." Jaffe, Public Actions 1270. Case titles furnish no clues because the King or Queen are "invariably the prosecu-

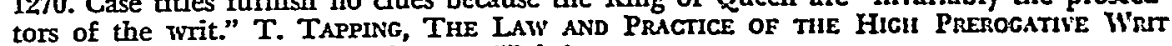
of MANDANus at vili (1848). Cf. note 57 infra.

49. E. Henderson 72; Jaffe \& Henderson, Judicial Review and the Rule of Law: Historical Origins, 72 L.Q. REv. 345, 359 (1956).

50. 77 Eng. Rep. 1271, 1277-78 (1615).

51. Rex v. Barker, 97 Eng. Rep. 823, 824-25 (1762).

52. Jaffe \& Henderson, supra note 49 , at $\mathbf{3 6 0}$.

53. De Smith notes that Mansfield seems to have been the first to perceive the close relationship between what are now classed as the "prerogative" writs. DE SMInI 384. 
offered financial inducements to strangers to prosecute such actions, provided for by a "very large" number of statutes "in which the public at large was encouraged to enforce obedience to statutes by the promise of a share of the penalty imposed for disobedience ..." ${ }^{44}$ Such informers had "no interest whatever in the controversy other than that given by statute," 55 and the pecuniary reward thus offered to strangers was little calculated to lead colonial lawyers to read cognate remedies narrowly. There were also the "relator" actions, deriving from the Crown's duty "to see that public bodies kept within their lawful powers." Blackstone cites the quo warranto statute of Queen Anne for a suit "at the relation of any person desiring to prosecute the same, (who is then styled the relator)...." ${ }^{57}$ The relator action flourished in England, where it is brought by the Attorney General "at the relation (i.e., at the instance) of some other person," being a proceeding "against any public authority which is abusing its power." "Is "It is not absolutely necessary," said Lord Hardwicke in 1741, that "relators in an information for a charity, should be the persons principally interested ... . [A]ny persons, though the most remote in the contemplation of the charity, may be relators in these cases"; and other cases dispensed with "the least particle of interest."

54. 4 W. Holdsworth, A History OF ENGlish LAW 356 (2d ed. 1937).

55. Marvin v. Trout, 199 U.S. 212, 225 (1905): "Statutes providing for actions by a common informer, who himself had no interest whatever in the contraversy other than that given by statute, have been in existence hundreds of years in England, and in this country ever since the foundation of our Government." The use of such actions to police official misconduct is noted by Blackstone, who refers to suits for forfeitures by persons who "being in particular offices ... neglect to take the oaths to the government; which penalty is given to him or them that will sue for the same." 2 W. BLAckstone, Cast. MENTARIES* 437. A New York informer's statute of 1692 to restrain privatcers and pirates provides for one-half the recovery of fines against an "officer that shall omitt or neglect his duty herein." Supreme Court of the Judicature of THe Province of New York, 1691 . 1704, 30 n.77, 71 n.74 (1959).

56. WADE 113 .

57. 3 W. Blackstone, Commentaries* 264. He also alludes to informations cxhibited in the name of the king, in which, "though the king is the nominal prosecutor, yet it is at the relation of some private person or common informer . . 4 id. 308 . A couple of pre-1788 relator cases are Attorney General v. Parker, 26 Eng. Rep. 1132 (Ch. 1747) (action to set aside election to a curacy); Attorney General v. Middleton, 28 ling. Rep. 210 (175I) (action concerning charitable trust for a school; dismissed because colored by relator's private motive of revenge).

58. WADE 113.

59. Attorney General v. Bucknall, 26 Eng. Rep. 600 (Ch. 1741). See Rex v. Mayor of Hartford, 91 Eng. Rep. 325 (1700). See also Attorney General v. Vivian, 38 Eng. Rep. 88 , 92 (1825): "The character of relator ... does not seem to require the least particle of private interest in the due administration of that charity." To the same cffect see Attorncy General v. Logan, [1891] L.R. 2 Q.B. 100, 103. Professor Wade states that

To require public authorities to keep within their powars generally is nat normally

the business of the ordinary citizen. But it is the business of the Crown, and the Crown will lend its help to any subject who reasonably wants to borrow-or rather to hire-it .... [I]t is a beneficial arrangement, since it enables a private citizen to assert his concern as a member of the public that public authorities should not abuse their powers. WADE 114. 
At the adoption of the Constitution, in sum, the English practice in prohibition, certiorari, quo warranto, and informers' and relators' actions encouraged strangers to attack unauthorized action. So far as the requirement of standing is "used to describe the constitutional limitation on the jurisdiction of this Court to 'cases' and 'controversies" ";0 so far as "case" and "controversy" and "judicial power" "presuppose an historic content";01 and so far as the index of that content is the "business of the . . . caurts of Westminster when the Constitution was framed,"62 the argument for a constitutional bar to strangers as complainants against unconstitutional action seems to me without foundation. When the Gourt stated in Flast $v$. Cohen that

in terms of Article III limitations on federal court jurisdiction, the question of standing is related only to whether the dispute sought to be adjudicated will be presented in an adversary context and in a form historically viewed as capable of judicial resolution. It is for that reason that the emphasis . . is on . . ."a personal stake in the outcome" of the controversy, ${ }^{\text {is }}$

it misinterpreted English history. For that history discloses that one without a "personal stake," a mere stranger to the action complained of, was allowed to initiate and maintain an "adversary" proceeding in the public interest to challenge a jurisdictional usurpation. Such a proceeding was "historically viewed as capable of judicial resolution." Those who would complain that the evidence of English practice is scanty should remember that the argument to the contrary rests on no evidence at all, but on the mistaken assumption that the practice in such strictly private actions as tort and contract governed "public actions $^{22}$ as well. ${ }^{64}$

Professor Finer states that the Attorney General "invariably permits the use of his name." H. FINER, ENGLISH LOCAL GOVERNAIENT 220 (4th cd. 1950), quoted in Jaffe, Public Actions 1274 .

60. Barrows v. Jackson, 346 U.S. 249, 255 (1953); cf. C. W'ricirt, Federal Courts 36 (1963); Bickel 42.

61. Coleman v. Miller, 307 U.S. 433, 460 (1939) (Frankfurter, J., concurring).

62. Joint Anti-Fascist Refugee Comm. v. McGrath, 341 U.S. 123, 150 (1951) (Frankfurter, J., concurring). See TAN 5 supra.

63. 392 U.S. at 101. "If our constitutional notions of proper judicial business are grounded to a significant degree in history it is next to impossible 10 conclude-as was attempted in Frothingham-that a taxpayer's action does not fulfill the constitutional requisites of case or controversy." Jaffe, Private Actions 302.

Justice Harlan was closer to the mark in concluding that non-personal stake public actions are "within the jurisdiction conferred upon the federal courts by Article III." 392 U.S. at 130 . See also id. at 120.

64. See Tennessee Electric Power Co. v. TVA, 306 U.S. 118, 140 (1999). Even when tempted to disbelieve a witness, courts have said that "Afere disbelicf of testimony [not inherently incredible] is not the equivalent of evidence to the contrary:" Phillips $v$. Gookin, 231 Mass. 250, 251, 120 N.E. 691 (1918); Mosson v. Liberty Fast Freight Co., 124 F.2d 448, 450 (2d Cir. 1942); Eckenrode v. Pennsylvania R.R., 164 F.2d 996, 999 n.8 (3d Cir. 1947); Magg v. Miller, 296 F. 973,979 (D.C. Cir. 1924). 
Possibly entertaining doubts about Justice Frankfurter's reference to the "practices of the courts of Westminster," Flast v. Cohen adverted to the "uncertain historical antecedents of the case and controversy doctrine" and sought to bolster it by arguments derived from the separation of powers and advisory opinion doctrines, emerging with what were termed "implicit policies embodied in Article III."0s The phrase "cases and controversies" was explained primarily as defining "the role assigned to the judiciary in a tripartite allocation of power to assure that the courts will not intrude into areas committed to the other branches of the government." 66

Overemphasis of the "separation of powers," however, is apt to obscure the no less important system of "checks and balances." Judicial checks on legislative excesses represent a deliberate and considered departure from an abstractly perfect separation of powers, part of what Madison called a necessary "blending" of powers that was required to make the separation work. ${ }^{67}$ Litigation that challenges un-

65. 392 U.S. $83,95.96$ (1968).

66. Id. at 95. The Court was careful to separate the issue of "capacity to suc" from the question whether it had Article III jurisdiction of the subject matter.

"[W] $[$ hen standing is placed in issue in a case, the question is whether the person whose standing is challenged is a proper party to request an adjudication of a particular issuc and not whether the issue itself is justiciable." $1 d$. at 99-100.

In Berger, Executive Privilege v. Congressional Inquiry, 12 U.C.L.A.L. REv. 1288, 1912 (1965), I directed attention to the fact that this distinction had bcen drawn in Tileston v. Ullman, 318 U.S. 44, 46 (1943): "Since the appeal must be dismissed on the ground that appellant has no standing to litigate the constitutional question . . . it is unnecessary to consider whether the record shows the existence of a genuine case or controversy essential to the exercise of the jurisdiction of this court"; and also noticed in Willing v. Chicago Auditorium Ass'n, 277 U.S. 274, 289 (1928), where, although there was "no lack of a substantial interest of the plaintiff in the question" of standing, Justice Brandcis concluded that "still the proceeding is not a case or controversy within the mcaning of Article III . . ."

For a similar differentiation in the field of conflicts between the jurisdiction of a court over the subject matter-the power confided by a state to decide in the premisesand the capacity of a party to sue, see A. Ehrenzweic, Conflict of Laws 35, 71, 72, 120 (1962).

Flast goes on to state that whether "a particular person is a proper party to maintain the action does not, by its own force, raise separation of powers problems related to improper judicial interference with other branches." 392 U.S. at 100. Then, after stating that "in deciding the question of standing, it is not relevant that the substantive issues in the litigation might be non-justiciable," Flast declares that it is "nccessary to look to the substantive issues ... to determine whether there is a logical nexus between the status asserted and the claim sought to be adjudicated." Id. at 101-02. How the irrelevant thus again becomes relevant is too subtle for my comprehension.

67. Explaining the limitations of the separation of powers doctrine in Federalist 47, Madison said that Montesquieu "did not mean that these departments ought to have .. no control over, the acts of each other." In No. 48 he stated that "unless thicse departments be so far connected and blended as to give to each a constitutional control over the others, the degree of separation which the maxim requires, as essential to a frec government, can never in practice be duly maintained." So too, Davic met criticism in the North Carolina convention with the reply that

Montesquieu, at the same time he laid down this maxim, was writing in praise of

the British government. At the very time he recommended this distinction of powers, 
constitutional legislation does not constitute an "improper interference" with nor an "intrusion" into the legislative domain. No authority to make laws in excess of granted powers was "committed" to Congress; instead courts were authorized to check Congressional excesses. "Case or controversy," to be sure, seeks to confine the courts to what Madison termed cases of a "judiciary nature" as distinguished from a roving revision of legislation. Legislation is emphatically not for the courts; but after the legislative process is completed the courts may decide in the frame of litigation that a statute is invalid as a legislative usurpation. ${ }^{88}$ A legislative usurpation does not change character when it is challenged by a stranger; and judicial restraint thereon remains a "judicial" function, not an "intrusion," though undertaken at the call of one without a personal stake. ${ }^{.9}$ No hint that judicial restraint of legislative usurpation was to hinge on the suitor's "interest" is to be found in the records of the Constitutional Convention. Having made review available to curb usurpations of power not "committed" to Congress, the Founders could assume that traditional remedies in "cases" of a "judiciary nature" would be available to curb such excesses,

he passed the highest eulogium on a constitution wherein they were all partially blended.

4 J. Elliot, Debates in the Several State Contentions on the Adoption of the Federal. Constrtumion 121 (1881). See also Frankfurter \& Landis, Power of Congress Over Procedure in Criminal Contempts in "Inferior" Federal Courts-A Study in Separation of Pou'crs, 37 HARv. L. REv. 1010 (1924). In short, the separation of powers was tempered by a system of "checks and balances," and the reach of the separation in a given case must be evaluated against the purpose that the given "check" was to serve.

68 . For this reason, Justice Harlan seems to me mistaken in saying that "unrestricted public actions" would "go far toward the final transformation of this Court into the Council of Revision which, despite Madison's support, was rejected by the Constitutional Convention." Flast v. Cohen, 392 U.S. 83, 130 (1968) (dissent). For that Council was to participate in the enacting process by way of an Exccutive veto (in which the judges would take part), as distinguished from judicial review after enactment and in the course of litigation. The matter was put in a nutshell by James WVilson, who argued in behalf of judicial participation in the Council that "[i]t will be better to prevent the passage of an improper law, than to declare it roid when passed." 2 FarRaÑ 391. King unged the exclusion of judges because they "ought to be able to expound the law as it should come before them, free from the bias of having participated in its formation." 1 id. 98. Charles Pinckney also objected that such participation would "give a previous tincture to their opinions." 2 id. 298. See also Gerry, 1 id. 97. The Council of Revision was rejected, judicial participation and all.

That the judicial function was to begin after completion of the legislative process appears again in Wilson's statement to the Pennsylvania convention:

it is possible that the legislature . . may transgress the bounds assigned to it. and an act may pass, in the usual mode, notwithstanding that transgression; but when it comes to be discussed before the judges-when they consider its principles, and find it incompatible with the superior power of the Constitution, - it is their duty to pronounce it void.

2 J. Elyor, supra note 67 , at 446.

69 . Compare the reasoning of Justice Brett, infra note 108. Professor Jaffe also finds it difficult to accept the conclusion "that an issue in every other respect apt for judicial determination should be non-justiciable because there is no possibility of a conventional plaintiff-an issue in short in which every one has a legitimate interest but only as a citizen." Jaffe, Private Actions 305. 
particularly in light of their desire to leave all channels open for attacks on congressional self-aggrandizement. ${ }^{70}$

The history of advisory opinions similarly lends small comfort to insistence on a personal stake in protests against unconstitutional action. That history exhibits not so much a shrinking from "improper interference" with Congress as a desire to shield the judicial invalidittion of statutes from the "bias" of prior advice to Congress, a consideration that bulked large with the Framers. ${ }^{71}$ When Jefferson asked Chief Justice Jay in 1793 whether President Washington might avail himself of the advice of the Justices on questions arising out of the FrancoBritish war, Jay called attention to the fact that the constitutional authority to call for the opinion of the Cabinet "seems to have been purposely as well as expressly limited to the executive departments." In addition, Jay remarked that the three departments "being in certain respects checks upon each other, and our being judges of a court in the last resort, are considerations which afford arguments against the propriety of our extra-judicially deciding the questions alluded to . . "73 By this time several Justices had decided in a number of cases on Circuit, in one of which Chief Justice Jay participated, ${ }^{74}$ that, as Justice Chase phrased it in 1800, "the supreme court can declare an act of congress to be unconstitutional and therefore, invalid ..." Jay's

70. See p. 834 infra.

71. Hamilton explained in Federalist 73 that one reason judges were excluded from the executive veto was that "the judges, who are to be the interpreters of the law, might receive an improper bias, from having given a previous opinion in their revisionary capacities ...." Hamilton is richly confirmed by the statements of the framers themselves. Strong opposed judicial participation in the Council of Revision because " $t]$ he Judges in exercising the function of expositors might be influerced by the part they had taken, in framing the laws." 2 Farrand 75. To the same effect see Gorham, id. 79, Rutledge, id. 80, Pinckney, 2 id. 298. King urged exclusion of the judges because "they ought to be able to expound the law as it should come before them, free from the bias of having participated in its formation." $l$ id. 98.

72. 3 H. Johnston, Correspondence and Public Papers of John JAY 486.89 (1891).

In the convention Gharles Pinckney had proposed a provision which would allhorize both Congress and the President "to require the opinions of the supreme Judicial Court upon important questions of law ..."That provision was referred to the Committce on Detail and was heard of no more. FARRAND 341,334 . Instead there erherged the present Article II, Section 2, clause 1 provision authorizing the President to requirc the opinions of the Departiments.

73. $3 \mathrm{H}$. Johnston, supra note 72 , at $486-89$.

74. The Circuit Court cases are reported in a note to Hayburn's Case, 2 U.S. (2 Dall.) $408,409-14$ (1792); that of Jay's Circuit at 409.

75. Cooper v. Telfair, 4 U.S. (4 Dall.) 14, 18 (1800):

It is, indeed, a general opinion, it is expressly admitted by all this bar, and some of the judges have, individually, in the circuits, decided, that the supreme court can declare an act of congress to be unconstitutional, and therefore, invalid; but there is no adjudication of the supreme court itself upon the point. I concur, however, in the general sentiment....

Earlier Justice Iredell had adverted to the judicial power to sct aside unconstitutional acts in Ware v. Hylton, 3 U.S. (3 Dall.) 199 (1796), and in Calder v. Bull, 3 U.S. (8 Dall.) $386,395,399$ (1798). 
emphasis that the courts were to serve as a check on the other departments indicates that the chief objection to "advisory opinions" was that the Justices were loath to render "extra-judicial" advice on questions that might later come before them for judicial decision. His desire to insulate constitutional decisions from the tug of prior judicial advice suggests no fear of improper intrusion into the congressional sphere; nor would decision of a stranger's suit render probable a biased declaration of unconstitutionality. In view of the fact that under the English practice attacks on jurisdictional excesses had traditionally been welcome, a logical nexus between "advice" and such attacks needs to be demonstrated, not assumed. ${ }^{70}$ So, too, Professor Frankfurter's argument against submission to the courts for advice of "legislative proposals rather than deliberate enactments," and his statement that such "advisory opinions are bound to move in an unreal atmosphere" 77 can have little bearing on a suit instituted by the American Civil Liberties Union to test an already enacted measure. ${ }^{73}$ An advisory opinion in response to a Congressional solicitation may be undesirable for a variety of reasons of policy, but it cannot be said to constitute an "intrusion" or "improper interference."79 Its only relevance to the

76. At least as regards a stranger's attack on unconstitutional action, the Flast statement that "the rule against advisory opinions implements the separation of powers prescribed by the Constitution and confines federal courts to the role assigned them by Article III," 392 U.S. at 96, seems to me unilluminating.

77. Frankfurter, Advisory Opinions, in 1 Excyc. Soc. Scr. 475,478 (1930).

78. Frankfurter, Advisory Opinions, in 1 Excyc. Sounders, "advice" to Congress before enactment was altogether different

from adjudication of a suit challenging the constitutionality of an enacted bill. If this seems an uncertain distinction to our subtle-minded generation, it was amply clear to the founders. See note 68 supra.

79. Even less can the term "intrusion" be applied to a statute whercby Congress authorizes a stranger to challenge the constitutionality of a law. Judicial entry in response to an invitation cannot constitute an "improper interference." From the beginning. the First Congress recognized that its own constitutional interpretations as a prelude to legislating were necessarily subject to judicial review. Thus, Peter Sylvester said, "If we are wrong, they can correct our error," I ANNAIS of CoNc. 585 [1789] (1834) (print bearing running page-head: Gales \& Seaton's History of Debates in Congress); John ing running page-head: Gales the laws shall be in violation of any part of the Constitution, the judges will not hesitate to decide against them," id. 505; Fisher Ames: "if vic declare improperly the judiciary will revise our decision," id. 496; Abraham Baldwin: "if Uicy find this

clause to be unconstitutional, they will not hesitate to declare it so," id. 582; Elbridge
Gerry: "Our exposition, therefore, would be subject to their revisal," id. 596.
The possibility that thereby he might be saved from his nistakes, said Congressman Elias Boudinot, gave him added confdence in carrying out his legislative taslis:

The last objection was that by adopting this bill [of which Boudinot was a proponent] we exposed the measure to be considered and defeated by the Judiciary ... who might adjudge it to be contrary to the Constitution, and therefore void . . This, he alleged, gave him no uneasiness. He was so far from controverting this right in the Judiciary, that it was his boast and his confidence. It led him to greater decision on all subjects of a constitutional nature, when he reflected that if, from inattention, want of precision, or any other defect, he should do wrong, that there was a power in the Government which could constitutionally prevent the opera. tion of such a wrong measure from effecting his constituents. He was legislating for a nation, and for thousands unborn; and it was the glory of the Constitution that there was a remedy even for the failures of the supreme Legislature itself. 
"standing" issue lies in its character as a non-judicial, non-"case or controversy" function; and in that aspect it is irrelevant to the propriety of a stranger's suit which was traditionally adjudicated by the English courts and was therefore comprehended as a "case" of a "judiciary nature."

But, it may be asked, does it follow that American judges, acting under a novel written constitution that set up three co-equal branches, were bound to follow the English practice when strangers attacked unconstitutional actions by Congress or the President? For the American legislature and executive occupied a far more exalted position than the petty officials and inferior courts that the King's Bench had been wont to keep in bounds.

We must remember that the present stature of Congress by no means corresponds to the place it occupied in the minds of the Founders. For them Congress was an object not of awe but of apprehension. They were far more anxious to defend against unconstitutional action by Congress than were English judges to curb unauthorized action by subordinate public bodies. At the several conventions the atmosphere was charged with an almost obsessive concern with Congressional "usurpations," and a drumfire of criticism was directed against feared congressional "tyranny" and "oppression." A few examples must suffice. Gouverneur Morris considered "[l]egislative tyranny the great danger to be apprehended." 80 Without "effective checks" against legislative "encroachments," said Madison, "a revolution . . . would be inevitable." 11 James Wilson warned against the danger of "legislative despotism." 82 This from advocates of the Constitution. In the Ratification conventions opponents such as Patrick Henry said, "I trust I shall see Congressional oppression crushed in embryo." 83 In North Carolina, Timothy Bloodworth warned that "[w]ithout the most express restric-

2 ANNALs, supra at 1978.79 [1791]. In his Lectures on the Law in 1791, Justice James Wilson, who had been a leading participant in both the federal and Pennsylvania Ratification conventions, and was then also Professor of Law, quoted Boudinot's statement. 1 J. WILSON, Works 330-31 (McCloskey ed. 1967).

80. 2 FARRAND 551, 76.

81. Id. 35. Though Madison and Morris were here concerned with state cxcesses, Madison also referred to the "strong propensity" of state legislatures "to a variety of pernicious measures" and stressed the need "to controul the Natl. Legislre. so far as it might be infected with a similar propensity." 2 id. 110. Mason stated that the national legislature "would so much resemble that of the individual States, that it must be ex. pected frequently to pass unjust and pernicious laws. This restraining power was thercfore essentially necessary." $I d$. 78. "All agree," said Nathaniel Gorham, "that a check on the Legislature is necessary." Id. 79.

82. 1 id. 261: "May there not be legislative despotism if in the exercise of their power they are unchecked or unrestrained by another branch?"

83. 3 Elliot 546; cf. id. 396. 
tions," going beyond those contained in the proposed Constitution, "Congress may trample on your rights." 84 There were others. ${ }^{85}$

To quiet such fears there were repeated assurances that Congress "has no power but what is expressly given it,"86 that it has "no authority" to make a law "beyond the powers" enumerated, si that "[i]f Congress, under pretence of executing one power should in fact usurp another, they will violate the Constitution."ss The legislature, said Archibald Maclaine in North Garolina, "cannot travel beyond [the Constitution's] bounds"; 89 it cannot, Governor Johnston added, "assume any other powers than those expressly given [it], without a palpable violation of the Constitution." 90 A law "not warranted by the Constitution," said James Iredell, a leader of the adoption forces in the same convention, "is barefaced usurpation." convention that "[w] $[\mathrm{w}$ ) a question arises with respect to the legality of any power, exercised or assumed by Congress" the question will be "Is it enumerated in the Constitution? ... It is otherwise arbitrary and unconstitutional."92 As Iredell said in North Carolina, "the question .. . will always be, whether Congress had exceeded its authority." Any assumption that congressional excesses were regarded more indulgently than were the "usurpations" of the English magistracy simply

84. 4 id. 167.

85. E.g., William Lenoir in North Carolina: "When we consider the great powers of Congress, there is great cause for alarm." Id. 203. "Lct us," William Lancaster there said, "exclude the possibility of tyranny," id. 213; and William Goudy warned, "beware the iron glove of tyranny." Id. 10. The ratification debates are replete with remarks to the same effect. See generally R. Berger, CoNgress v. TuE Surkeme Coumt (to be published: Harvard University Press, 1969). As Jefferson was later to say:

It is jealousy and not confidence which prescribes limited constitutions to bind down those whom we are obliged to trust with power. Our Constitution has accordingly fixed the limits to which, and no further, our confidence will go. In questions of power, then, let no more be heard of confidence in man, but bind him down from mischief by the chains of the Constitution.

Quoted in C. WARREN, CoNGress, the Constrtution aNd the Surrese Court 153 (1925).

86. 3 ELLIot 464 (Randolph).

87. 4 Id. 166 (MacLaine). In Massachusetts, Samuel Stillman acknowledged that Congressional powers were "great and extensive" but maintained that they are "defined and limited, and ... sufficiently checked." 2 id. 166.

88. 4 id. 179 (Iredell).

89. Id. 63; see also id. 140-41.

90. Id. 142.

91. Id. 194.

92. 3 Id. 186

93. 4 id. 179. Earlier Iredell expressed the "utmost satisfaction" with the "jealousy" and extreme caution with which gentlemen consider every pover to be given to this government." 4 id. 95 . See also p. 834 infra.

When Chief Justice Shaw relied on "respect for the legislature" and "well-established principles" to bar a stranger's assault on a state law, Wellington, Petr., I6 Pick. (33 Mass.) 87, 96 (1834), he did not, of course, take account of the relevant history of the Federal Constitution, nor did he mention the relevant English practice in prohibition, certiorari, and the like, but concluded that an unconstitutional Act was merely voidable. not void, and consequently could be challenged only by those persons whose rights were affected. 
does violence to the facts. Rather, I would say, the founders raised the English policy of policing jurisdictional excesses to the highest power.

In the process they were not content with assurances that congressional transgressions would be void and would be so declared by the courts, ${ }^{94}$ but stressed that all channels of resistance remained open. Thus Parsons stated in the Massachusetts convention that "[a]n act of usurpation is not obligatory; it is not law; and any man may be justified in his resistance."95 In North Carolina Steele said, "[i]f the Congress make laws inconsistent with the Constitution, independent judges will not uphold them, nor will the people obey them. $A$ universal resistance will ensue." 96 Even so fervid a proponent of judicial review as Iredell said that "[t]he people will resist if the government usurp powers not delegated to it." ${ }^{\circ}$ Would proponents of the Constitution have preferred "universal resistance" to a suit by a disinterested representative of the public interest that would resolve the issue peaceably? One who pores over the ratification debates is driven to conclude that the founders must have welcomed any traditional mechanism that could aid in keeping Congress within bounds.

Two early, post-1787 state cases indicate how naturally American courts did in fact adapt English practice to the problem of dealing with invalid laws. Zylstra $v$. Charleston arose on a motion for a prohibition to restrain an inferior court from levying a fine (under a city ordinance) that was allegedly "unconstitutional and out of its jurisdiction." The threatened action was held "void, as being contrary to the constitution of the state," and a prohibition issued. ${ }^{8}$ In State v. Corporation of New Brunswick a citizen moved for certiorari to the mayor to return a by-law of the corporation in order to test its validity. Agninst

94. In Federalist 78, Hamilton alluded to the "clear principle" that "cvery act of delegated authority, contrary to the tenor of the commission, under which it is exercised, is void. No Iegislative act, therefore, contrary to the Constitution, can be valld." If Congress exceeds its powers, said George Nicholas in the Virginia convention, "the judiciary will declare it void." 3 ELLIOT 443. Samuel Adlams said in the Massachusctts convention that "any law ... beyond the power granted by the proposed constitution ... [will be] adjudged by the courts of law to be void." 2 id. 131. Oliver Ellsworth told the Connecticut convention that "a law which the Constitution does not authorize" is vold, and the judges "will declare it to be void." Id. 196. Similar statements were minde by Wilson in Pennsylvania, 2 id. 446, and by John Marshall in Virginia, 3 id. 553.

95. 2 id. 94.

96. 4 id. 71 .

97. Id. 185. In the First Congress Madison teferred to "the general principle, that laws are unconstitutional, which infringe rights of the community." 1 ANNALs, stupra note 79 , at 458 [1789]. Colonists considered that "no obedience is due to arbitrary, un. constitutional edicts," and that "the invasion of the liberties of the people "constitutes a state of war with the people' who may use 'all the power which God has given to them' to protect themselves." B. BAILyN, THE IDEOlogical Origins of the AMErican Rtvolution 142 (1967).

98. I Bay 382, 390 (S. C. 1794). 
the motion it was argued that "[t]he court ought not to award a certiorari on the mere prayer of an individual, unless he will previously lay some case before them tending to show that he is or may be affected by the operation of the by-law, and is, therefore entitled to question its validity." The court ignored this argument and issued the writ.93 $\mathrm{Al}$ though these cases dealt with minor governmental bodies, the fact remains (1) lack of jurisdiction was matter-of-factly equated with unconstitutionality, and (2) a personal interest was not deemed necessary for an attack upon the validity of a law. Of course this is not conclusive evidence that contemporary judges had generally assimilated English practice to the American condition, ${ }^{100}$ but it is better than unsubstantiated twentieth century speculation that would assign our values to the eighteenth century founders.

Flast $v$. Gohen makes yet another dubious contribution to the alleged constitutional derivation of "standing" in the shape of a distinction between a "challenged enactment [that] exceeds specific constitutional limitations," e.g., express prohibitions, and one that "is generally beyond the powers delegated to Congress." 101 Whatever its desirability on policy grounds, the distinction seems to be without historical warrant. Little stress was placed in the several ratifying conventions on the possibility that Congress might act in defiance of express Constitutional prohibitions; the gnawing fear was rather that Congress might usurp powers in excess of those conferred. To cite only a few examples, Wilson assured the Pennsylvania convention that if any congressional act should be "inconsistent with those powers vested by this instrument in Congress, the judges, as a consequence of their independence, and the particular powers of the government being defined, will declare such laws to be null and void." 102 Archibald MacLaine said in the North Carolina convention that "[i]f Congress should make a law beyond the powers and spirit of the Constitution, should we not say to Congress, 'You have no authority to make this law. There are limits beyond which you cannot go. You cannot exceed the power prescribed

99. I N.J.L. 393 (1795). Mark that this argument was cast in terms of what is now called "standing," not in terms of a failure to state a cause of action because of damnum absque injuria. Cf. note 47 supra.

100. But see Strong's Case, Kirby 345, 351 (Conn. 1785-88), where counsel on both sides cited English law on mandamus and the court laid down that the "statute of Anne should be the rule of the proceeding." Colonial reliance on English authority was the practice. See notes 24 \& 25 supra.

101. 392 U.S. at 102-03. For Justice Fortas, concurring, "This thesis, slender as its basis is, provides a 'nexus' for the action." Id. at 115. Cf. Justice Douglas, concurring, id. at 110 .

102. 2 ExLioT 489. 
by the Constitution.' "103 Policing of such excesses was paramount in the minds of the founders, and it may fairly be concluded that they expected that both jurisdictional usurpations and defiance of prohibitions would equally be set aside. Thus Hamilton coupled the two forms of excess when, in Federalist 78, arguing from principles of agency, he derided the notion that those who act under delegation "may do not only what their powers do not authorize, but what they forbid." Similarly Luther Martin, who opposed the Constitution, understood nonetheless that the judicial power extended both to Acts "contrary to" and to those "not warranted by the Constitution ..."104 With Justice Harlan, I am "quite unable to understand, how, if a taxpayer believes that a given expenditure is unconstitutional . . . his interest in the suit can be said necessarily to vary according to the constitutional provision under which he states his claim."10v

103. 4 id. 161. Governor Johnston reassured North Carolina: "The powers of Congress are all circumscribed, defined, and clearly laid down. So far they inay go, but no farther." 4 id. 64. See also id. 185, 188. In the Massachusetts convention, Samucl Adams said that the courts would adjudge "void" any federal law "extended beyond the power granted by the proposed Constitution." 2 id. 131. And John Marshall told the Virginia convention that were Congress to "go beyond the delegated powers," "to make a law not warranted by any of the powers enumerated," the courts would "clcclare it void." 3 id. 553. See also p. 833 supra.

104. 3 FARRAND 220.

105. Flast v. Cohen, 392 U.S. 85, 124.

We have seen that the English practice did not require statement of a "causc of action" as a prelude to maintenance of what Professor Jaffe has aptly termcd a "public action." See note 11 supra. As regards such actions, I would therefore dissent from Pro. fessor Wechsler's view that the judicial power extends to all cases arising under the Constitution "only when the standing law, decisional or statutory, provides a remedy to vindicate the interest that demands protection ... "Wechsler, Toward Neutral Prin. ciples of Constitutional Law, 73 HARv. L. REv. 1, 6 (1959), assuming that by such "interest" he means a "personal stake." My own reading in the records of the several conventions turned up no relevant limitation beyond Madison's proposal to confine $\Lambda \mathrm{r}$ ticle III to cases of a "judiciary nature." Suits by strangers were of that naturc. To make existence of a "remedy" a component of the Article III power raises still other" problems. Suppose there is a deprivation of constitutional rights for which no "remedy," statutory or decisional, exists, can it be that such a case "arising under the Constitution" lies outside the "judicial power"? Can it be that an invasion of constitutionil rights would be without remedy? If the Constitution provides its own "remedy" in such cases, we are engaged in circular reasoning. Suppose that the Court proceeds to fashion a ncw remedy-Marshall laid claim in Marbury $v$. Madison to the common law power to fashion a remedy for the protection of every right, 5 U.S. (1 Cranch) 137, 168 (1808)and suppose that the existence of a remedy is an indispensable element of "judicial power"; is not this the creation of bootstrap jurisdiction? Analytically, the Article III "judicial power" is jurisdictional, and to make it depend upon the availability of remedies is to leave the jurisdiction at the mercy of Court or Congress, who can then contract it at will.

Elsewhere I have sought to show that the Article III authorization to makc "cxcep. tions" to the Supreme Court's appellate jurisdiction was not designed to permit Congress to deprive the Court of jurisdiction of constitutional controversics, that a federal courteither an inferior court or the Supreme Court on appeal from a state court-must be open for assertion of a constitutional right, and that Congress's power to withdraw or withhold consent to suit likewise may not be employed to bar access to a federal court for relief from federal invasions of Constitutional rights. R. BERGER, Congkess v. TuE SUPREME Court (to be published: Harvard University Press, 1969).

The judicial power, I submit, is best viewed as a constitutional grant of juriscliction of 
There remains the question whether allowance of a suit by a stranger who lacks a personal interest to challenge action that is in excess of power granted by the Constitution lies within judicial discretion or is a matter of right. Except for prohibition, issuance of the other prerogative writs-mandamus, certiorari, and quo warranto-seems clearly to have been a matter of judicial discretion. ${ }^{100}$ Coke's record of Articulo Cleri, however, suggests that the writ of prohibition would issue as a matter of right. Replying in the Tenth Answer to the objection that a plaintiff who sued in the ecclesiastical court should be precluded from obtaining prohibition of his own action, the judges stated:

None may pursue in the ecclesiastical court for that which the kings court ought to hold plea of, but upon information thereof given to the kings courts, either by the plaintife, or by any mere stranger, they are to be prohibited, because they deal in that which appertaineth not to their jurisdiction ... [P]rohibitions thereupon are not of favour, but of justice to be granted.107

the subject matter described in Article III, which exists independently of whether a litigant can state a cause of action. A word is in order about the mistaken identification of jurisdiction with failure to state a cause of action, of which the classic example is Tennessee Elec. Power Co. v. TVA, 306 U.S. 118, 140, 147 (1939). In that case eighteen power companies sought to enjoin operation of the Tennessec Valley Authority, ascerting that it lacked constitutional power to act in the premises. The Court held that the plaintiff lacked standing because the "damage consequent on competition, otherwise lawful, is in such circumstances damnum absque injuria . ..." id. 140, the Latin tag generally associated with injuries that do not give rise to a cause of action. Compare. note 47 supra. Failure to state a cause of action is not nomally regarded as jurisdictional; it "calls for a judgment on the merits and not for a dismissal for want of jurisdiction." Bell v. Hood, 327 U.S. 678, 682 (1946). One may hase a cause of action and fail, for example, to come within the "diversity" jurisdiction of Article III, or come within that jurisdiction and fail to state a cause of action. Justice Frankfurter justly objected to "confounding the requirements for establishing a substantive cause of action with the requirements of diversity jurisdiction." Smith v. Sperling, 354 U.S. 91, 98 (1957) (dissent); Romero v. International Terminal Co., 358 U.S. 354, 359 (1959). No more should the other branch of the "judicial power"-"case or controversy"-be identified with statement of a cause of action. It needs to be kept firmly in nind that "a court may have jurisdiction of the subject matter of an action though the complaint therein does not state a claim upon which relief can be granted." Weiss v. Los Angeles Broadcasting Co., 163 F.2d 313, 314 (9th Cir. 1917). "Jurisdiction . . . is not defeated . . . by the possibility that the averments might fail to state a cause of action." Bell v. Hood, 327 U.S. 678, 682 (1946).

106. Certiorari: I M. BaCon, ARridgment, "Certiorari" (A) (3d cd. 1768); Rex v. Lewis, 98 Eng. Rep. 288 (1769); Regina v. Justices of Surrey, [1870] L. 5 Q.B. 466, 472-73.

Quo Warranto: For early statutory requirement of leave of court, see Sirontr 113.14; Rex v. Trelawney, 97 Eng. Rep. 1010 (1765); Rex v. Wardroper, 98 Eng. Rep. 23 (1760). Mandamus: 3 M. BACON, ABRIDGMent, "Mandamus" (E) (3d ed. 1765): the Court of King's Bench "are not obliged to [issue mandamus] in all Cases wherein it may secm proper, but herein may exercise a discretionary power, as wcll in refusing, as granting such Writ ..."

107. 2 INST: 607. Blackstone states that from Articulo Cleri "much may be collected concerning the reasons of granting and methods of proceeding upon prohibitions." 3 W. Blackstone, Conmentaries" 113. Professor Henderson states that the "theoretical emphasis" of the seventeenth and eighteenth centuries "was on "jurisdiction," an elusive concept of the agency's or justices" 'power' to hear the question at all or to take a given action. Questions that had been labelled as "jurisdictional" could be reviewed as of right." HeNDERSON 6. 
In modern terms, such writs would issue as of right. Articulo Gleri remained vital in England, where in 1875 its principles were powerfully restated in Worthington $v$. Jeffries by Justice Brett. ${ }^{108}$

Our concern, however, is with how English law appeared to the eyes of a colonial lawyer who did not have the benefit of nineteenth century cases. It is generally acknowledged that at the time of the Revolution and before, there was considerable disagreement as to whether prohibition, even in the case of one who had a personal interest, was a matter

108. These authorities show that the ground of decision, in considering whether prohibition is or is not to be granted, is not whether the individual suitor has or has not suffered damage, but is, whether the royal prerogative has becn encroached upon by reason of the prescribed order of administration of justice having becn disobeyed. If this were not so, it seems difficult to understand why a stranger may interfere at all .... If it is the absolute duty of the superior Court to enforce order on being convinced of a breach of it by information given by the defendant in the suit below, why should it be a less absolute duty if it is convinced of the same breach of order by information given by a stranger? Order is no less broken, the prerogative is no less invaded .... [T] he real ground of the interference by prohibition is not that the defendant below is individually damaged, but that the cause is drawn in aliud examen, that public order in administration of law is broken. And inasmuch as the duty of enforcing such order is imposed on the superior Courts, and the issue of a writ of prohibition is the means given to them by law of enforcing such order, it seems to us that, upon principle and in the ab. sence of enactment, it must be their duty to issue such writ whenever they are clearly convinced by legal evidence, by whomsoever brought before them, that an inferior Court is acting without jurisdiction, or exceeding its jurisdiction. . . .

Justice Brett further remarked that in Articulo Cleri "the duty is declared in absolute terms applicable to all cases."

L.R. 10 C.P. $379,382,383$.

Although the nineteenth century English cases exhibit some differences of opinion, the later and more numerous cases are with Brett. Among the latter is Burder v. Velcy, 113 Eng. Rep. 80I (Q.B. 1840), where Denman, C.J., stated: "In whatever stage that fact ['want of jurisdiction'] is made manifest, either by the Crown, or by any onc of its subjects, we are bound to interpose," id. at 812-13; "the Courts of Westminster Hall have no discretion to award or refuse the writ, but are bound to award it." $1(d$. at 810 . An influential case contra is Forster v. Forster, 4 B. \& $S .187,199$ (Q.B. 1863), in which Cockburn, C. J., distinguished the case of a stranger from that of a party aggricved, stat. ing that although the Court will listen to a stranger, "[Y]et this is not ex debito justitiae, but a matter upon which the Court may properly exercise its discretion. . . " Cockburn's statement apparently was approved in Mayor of London v. Cox, [1865] L.R. 2 E. \& I. App. 239,280 (H. L.), where the same point "came indirectly before the House of Lords." So Master of Rolls Jessel concluded in Chambers v. Green, [1875] L.R. 20 Eq. Cases 552, 555, choosing to rely on Forster and Cox rather than on the subscquent opinions in Worthington v. Jeffries. When Chambers $v$. Green was later pressed on Justice Brett, he adhered to Worthington in Ellis v. Fleming, [1876] L.R. 1 C.P. Div. 287, $239-40$.

In Farquharison v. Morgan, [1894] 1 Q.B. 552, 556, the Court of Appeals followed the Coke rule; Lord Halsbury stated:

It has long been settled that, where an objection to the jurisdiction of an inferior Court appears on the face of the proceedings, it is immaterial by what means and by whom the Court is informed of such objection. The Court must protect tho prerogative of the Crown and the due course of the administration of justice by prohibiting the inferior Court from proceeding in matters as to which it is ap. parent that it has no jurisdiction.... I find no authority justifying the withholding of a writ of prohibition in such case.

Professor de Smith states that "If a defect of jurisdiction is apparent on the face of the proceeding, the application may be brought ... by a complete stranger . . . and the court is obliged to allow the application." DE SMiri 427. 
of discretion or of right. ${ }^{109}$ When regard is had to this division of opinion, noted in Bacon's Abridgment, ${ }^{110}$ and to the discretionary nature of the other prerogative writs, it is difficult to attribute to colonial lawyers the view that the writ of prohibition had to issue to a stranger as of right. Neither, however, may we attribute to them the view that prohibition could be denied out of hand, for Bacon's $A$ bridgment emphasized that "the Superior Courts are at liberty to exercise a legal Discretion herein, but not an arbitrary one, in refusing Prohibitions, where in such like cases they have been granted ...."111

Finally, there appears to be no impediment to the creation by Congress of an absolute right to prohibition, even when sought by a stranger. ${ }^{112}$ It has never been suggested that there are any limits on the creation of the cognate "informers" actions, which create indefeasible causes of action at least until Congress withdraws jurisdiction from the courts.113 Taking note of the "informers" statutes, and doubtless cognizant of "relators" actions as well, Judge Jerome Frank drew from FCC v. Sanders Brothers Radio Station " and Scripps-Howard Radio, Inc. v. FGC $C^{115}$ the proposition that "Congress can constitutionally enact a statute conferring on any non-official person . . . authority to bring a suit to prevent action by an officer in violation of his statutory powers; for then ... there is an actual controversy. . . Such persons, so authorized, are so to speak, private Attorney Generals."110 TWhen this statement appeared in 1943, those who were under the spell of the Court's earlier decisions regarded it as a daring break with tradition, whereas in fact it is solidly rooted in the common law. It is difficult to

109. Ford v. Welden, 83 Eng. Rep. 50 (1664); Clay v. Snelgrove, 91 Eng. Rep. 1285, 1286 (1701); Parish of Aston v. Castle-Birmidge Chapel, 80 Eng. Rep. 215 (c. 1603-1625). See also Major of London v. Cox, [1865] L.R. 2 E. \& I. App. 239, 278 (H.L.).

110. 4 M. BACON, ABRTOGMENT, "Prohibition" (B) (3d cd. 1768).

111. Id. Of the related quo warranto writ, Lord Mansfield said the Court must "exer. cise a sound discretion." Rex v. Wardroper, 98 Eng. Rep. 23 (1760).

There "is no clear decision that the court can use its discretion arbitrarily" in the field of certiorari, and discretionary denials of certiorari involve cases where cvidence "showed ground on which the adjudication attacked would be upheld." Gordon, Certiorari and the Problem of Locus Standi, 71 L.Q. REv. 483, 485 (1955).

112. For the contrary view, see note 10 supra.

113. Blackstone said that "by commencing the suit the informer has made the popular action his own private action, and it is not in the power of the crown, or of any thing but parliament, to release the informer's interest." 2 W. BLACkstoNe, Comisentanies 437. See also Sherr v. Anaconda Wire \& Cable Co., 149 F.2d 680, 681 (2d Cir. 1945), which held that Congress may deprive the district court of jurisdiction after the informer has filed his action, leaving him to seek compensation, if any, in the Court of Clains.

114. 309 U.S. 470 (1940).

115. 316 U.S. 4 (1942). For discussion of Sanders and Scripps-Houtard, see Jaffe, Privale Actions 272-74.

116. Associated Industries, Inc. v. Ickes, 134 F2d 694, 704 (2d Cir. 1943), r'acaled as moot, 320 US. 707 (1943). 
see how the power of Congress to confer standing by statute can be open to question when its power to create informers' actions is beyond doubt. ${ }^{117}$ Since the monetary recovery is only an incentive to, rather than an element of, the action, it cannot be that the payment of a financial inducement to a stranger alone legitimizes his suit. This would too much resemble Charles Lamb's Chinaman who thought it necessary to burn down the house in order to roast the pig.

In sum, the notion that the constitution demands injury to a personal interest as a prerequisite to attacks on allegedly unconstitutional action is historically unfounded. The "matters that were the traditional concern of the courts in Westminster" upon which such an interpretation of the "case or controversy" phrase has been premised were not in fact as limited as Frankfurter and his successors have supposed. Public suits instituted by strangers to curb action in excess of jurisdiction were well established in English law at the time Article III was drafted. Nor were the concerns of the Founders with separation of powers and advisory opinions germane to the issues involved in standing to challenge action either in defiance of or beyond the authority granted by the Constitution. There may well be policy arguments in favor of a "personal interest" limitation on standing, but they cannot rest on historically-derived constitutional compulsions.

117. Justice Harlan, who questions the wisdom of broadening the standing of strangers, states that "[a]ny hazards to the proper allocation of authority among the three branches of the Government would be substantially diminished if public actions had been pertinently authorized by Congress and the President." Flast v. Cohen, 392 U.S. at 116, 131-32 (1968) (dissent). See also note 79 stupra. 


\section{The Yale Law Journal}

Volume 78, Number 5, April 1969

$\begin{array}{ll}\text { Editor-in-Chief } & \text { JOHN TOWNSEND RICH } \\ \text { Executive Editor } & \text { RICHARD COTTON } \\ \text { Article \& Book } & \text { GEOFFREY DRURY } \\ \text { Review Editors } & \text { EDWARD L. STROHBEHN, JR. } \\ \text { Managing Editor } & \text { JOHN F. DIENELT } \\ \text { Note E Comment } & \text { ALEXANDER MORGAN CARRON } \\ \text { Editors } & \text { W. JOHN GLANCY } \\ & \text { DEAN HELIER } \\ \text { Projects Editor } & \text { BARRY E. CARTER } \\ \text { Projects Manager } & \text { RICHARD E. AYRES } \\ \text { Publication Editor } & \text { MICHAEL D. BARONE }\end{array}$

JUDITH C. AREEN KENNETH C. BASS III ALLEN R. BENTLEY James F. Blumistein RAYMOND P. BOULANGER JOHN E. BRYSON JEFFREY A. BURT WiLLIAXS A. BUtLER Charles B. Cannon Clifrord R. DaMamers JoHN F. DAUM LanNy J. Davis Richard D. DIAMOND Willuam Drayton, Jr. STEPHEN S. DUNhaM MICHAEL G. EGGER MAX FACTOR III HaMmLTON P. Fox III Paul R. Friedaran

Business Secretaties M. Olne Butterfied, Pasien Willsott

JOHN J. GEAREN Paul D. Gewirtz PETER J. GregorA ELEANOR S. GLASS JOHN P. GoDICH STEPHEN HOCHBERG GARY N. Jacobs MICHAEL I. JEFFERY Wifliam H. Jefreres, Jr. Irving S. Schloss Wilitam E. Kane Martin L. Senzel ALAN D. KEISER JOHN W. KERER DUNGAN M. KENNEDY JONATHAN L. KROWN JOHN C. LADD THOMAS M. LEMgaERG DaNiel M. LEWis LINDSAY A. LOVEJOY, JR. JOHN R. LUCAS, JR.
DAVID B. LITLE ANGus C. MIAcBeth ROBERT D. MCLEAN RONALD W. AIEISTER David N. Roses RANd E. Rosenalatt Barry A. SANiders ThoMeas SCARLETT Howard F. Shattuck III KENNETH I. SIDLE STEVEN L. SLOCA JAMIES G. SPETh, JR. Robert S. VenNiNic GARY C. WALKER Melvin L. Watt Peter H. WEINER RICHARD A. ZIMRIER

Student Contributors to This Issue

Duncan M. Kennedy, Civil Disabilities and the First Amendment William Henry Navin, Insiders' Liability Under Rule 10b-5 for the Illegal Purchase of Actively Traded Securities 